\title{
Investigating director development in South Africa
}

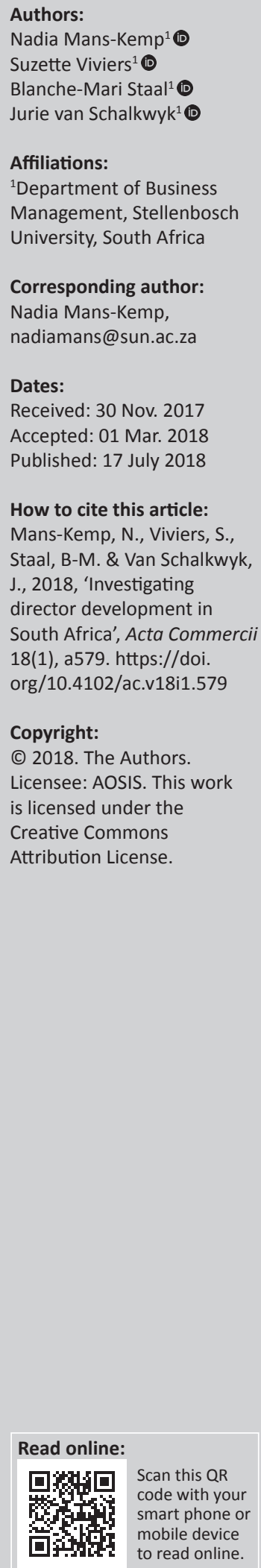

Orientation: To effectively fulfil their multiple roles, the four King Reports suggest several development mechanisms for newly appointed and seasoned directors.

Research purpose: This study investigated the most prominent King III director development initiatives used by the Johannesburg Stock Exchange (JSE) Top 40 companies over the period 2011-2015.

Motivation for the study: Despite the emphasis on director development in the King Reports, there is a paucity of academic research on the topic. The authors hence evaluated corporate reporting on and the application of selected director development mechanisms.

Research design, approach and method: A mixed-methods approach was adopted. Key words were used to conduct content analysis on the companies' integrated reports. Disclosure and depth scores were constructed to evaluate reporting trends. To gain further insight into these trends, semi-structured personal interviews were conducted with directors who had varying levels of experience.

Main findings: The majority of the JSE Top 40 companies disclosed some details regarding the director development initiatives they used. The key word analysis revealed that most companies focused their development efforts on new board appointees. The interviewees emphasised that the entire directorate should be continuously developed. Participants indicated that mentoring is an important informal development mechanism. In line with literature, they stressed that all directors should take personal responsibility for their development.

Contribution/value-add: This study emphasises the importance of continuous director development beyond the orientation of new board appointees. A well-developed board is in a better position to fulfil its responsibilities to shareholders and other key stakeholders than a less developed one.

\section{Introduction and background}

The inevitability of change has captured the attention of scholars since ancient times. The Greek philosopher Heraclitus (535 BC-475 BC) remarked that 'the only thing that is constant is change' (in Breverton 2009). Charles Darwin (1809-1882) added that, within a changing environment, 'it is not the strongest of the species that survives, nor the most intelligent, but the one most responsive to change' (in Van Marrewijk \& Werre 2003). Rapid technological developments over the last few decades have not only accelerated globalisation but have also increased the pace and magnitude of change in the corporate arena (Chinyio \& Olomolaiye 2010).

In a constantly changing business environment, a board that comprises well-developed individuals could give a company a competitive advantage (Collins \& Clark 2003; Davis \& Callahan 2012). According to the Institute of Directors in Southern Africa (IoDSA 2009), the board is regarded as the focal point of corporate governance. Directors are hence responsible for setting their companies' strategic direction, driving performance and monitoring managers' behaviour. The capabilities and performance of these individuals could thus considerably influence the prosperity of shareholders and other key stakeholders (Brown 2005; Schwizer, Casiraghi \& Stefanelli 2011).

In the aftermath of the 2008 global financial crisis, concerns were raised about directors' ability to fulfil their duties and a lack of enabling information (Wixley \& Everingham 2010). Companies are increasingly called upon to introduce and expand director development initiatives (Davis \& Callahan 2012). Moreover, directors are encouraged to engage in such initiatives at different stages of their careers. Consequently, the competencies of individual board members and the effectiveness 
of the directorate could improve (Coulson-Thomas 2008; Groves 2007)

The continuous development of directors is promoted by Institutes of Directors around the globe (International Institute of Directors and Managers 2017), including South Africa (IoDSA 2009). Given the country's unique sociopolitical history, local companies face several challenges in sourcing and appointing eligible, diverse board candidates. The first King Report on corporate governance was published shortly after the first democratic election in the country in 1994. This report laid the foundation for a well-developed corporate governance framework for companies listed on the Johannesburg Stock Exchange (JSE). The publication of three further King Reports strengthened this foundation.

The promulgation of the Companies Act (No. 71 of 2008) placed the spotlight firmly on the personal liability of directors. This Act pertinently states that directors of JSElisted companies could be held personally liable if they fail to fulfil their duties (Republic of South Africa 2008). Consequently, several director development initiatives have been proposed in this Act and the King Reports to enhance corporate governance practices in the local context. Despite these developments, limited academic research has been conducted on the topic in South Africa.

In this article, the authors hence argue that unless companies develop and support a culture of ongoing director development, corporate performance and, by implication, shareholders' wealth might not be optimised. It is therefore unsurprising that shareholders and stakeholders are increasingly requesting listed companies to continuously develop their directors (Roy 2008).

The following literature review will centre on the recommended composition and key roles of directorates as well as board development mechanisms including induction, briefings, continuous development, mentoring and coaching. Thereafter, the problem statement and research objectives are presented followed by a description of the mixed-methods approach. Based on a discussion of the findings, conclusions are drawn and recommendations offered. Suggestions for future research are made, based on the study's limitations.

\section{Literature review}

\section{The roles and composition of directorates}

Board members in a one-tier board system have both a monitoring and an advisory role (Chen 2008). In line with the agency theory, directors are expected to monitor the actions of managers on behalf of shareholders (Jensen \& Meckling 1976). The advisory function of directors entails the development of corporate strategies and policies, including those geared towards stakeholders.

Since 1994, a stakeholder-inclusive approach was advocated by the King Reports. The boards of directors of JSE-listed companies are thus accountable to their companies and responsible towards the relevant stakeholders (IoDSA 2002). As decisions made in the boardroom could have wide-ranging consequences, directors should develop the ability to function efficiently in a collective decision-making environment (Mallin 2005).

As outlined in the King III Report, nomination committees play an important role in determining the composition of a board. Committee members should give attention to the board's size and composition, including the status (executive, non-executive and independent), race, gender, age, industry knowledge and experience of board members (IoDSA 2009).

Given the associated advantages, calls are progressively made to diversify boards in the international context (Adams \& Ferreira 2009) and in South Africa (Viviers, Mans-Kemp \& Fawcett 2017). Some diverse board candidates, however, lack the skills to obtain a board position (Prinsloo \& Shevel 2013). Given the limited pool of eligible candidates in South Africa, companies are urged to broaden and deepen the talent pool (Viviers et al. 2017). Institutes of Directors are increasingly encouraging companies to orientate newly elected directors and offer ongoing development for all board members (IoDSA 2015). In King IV, reference is made to governing bodies, instead of boards of directors, to cover a wider range of public, private and not-for-profit organisations (IoDSA 2016).

Given the timeframe of the study (2011-2015), reference will be made to the director development guidelines contained in the King III Report. The discussed guidelines are also mentioned and, in some instances, expanded in King IV.

\section{Orientation, briefings and continuous development programmes}

As the roles of directors are multifaceted and complex, considerable attention should be given to their orientation (also called induction) (IoDSA 2015). King III recommended that a formal induction programme should be established to familiarise board appointees with the firm's operations, business environment and sustainability aspects (IoDSA 2009). Long (2008) pointed out that director induction became an institutionalised process during the 2000s. King IV, published in 2016, stresses that new members should be inducted to make 'the maximum contribution within the shortest time possible' (IoDSA 2016).

The primary aim of an orientation programme is to assist board appointees to understand their roles and responsibilities in order to contribute in a meaningful and timeous manner (IoDSA 2015). During the orientation process, teamwork should be promoted. Experienced directors could be invited to share their knowledge and experiences with their new colleagues (Long 2008; MacLean 2003).

In addition to being involved in an induction programme, both King III and King IV recommend that all members 
should receive timeous briefings on changes in their legal and operating environments and task requirements (IoDSA 2009, 2016). Such updates are especially valuable for nonexecutives, as they are not involved in the firm's daily operations (Walker 2009).

Director development can occur during different stages of a director's career (Davis \& Callahan 2012; Gregory \& Grapsas 2012; IoDSA 2009). When developing directors, Brown (2005) suggested that focus could be placed on their educational context and analytical abilities. Directors should be sensitised as to the importance of the contextual dimension covering corporate context and culture. The incorporation of the strategic dimension in training programmes could develop directors' ability to effectively conduct long-term planning. Development of interpersonal skills might furthermore enable board members to consider complex relationships within the micro and macro environments. Finally, directors should be trained to properly account for the political and legal dimensions.

Listed companies could develop their boards internally and use external service providers (Davis \& Callahan 2012; Haskins \& Shaffer 2009). Directors should furthermore be encouraged to engage in self-improvement activities, for example attending corporate events, conferences and informal networking opportunities (Gregory \& Grapsas 2012).

Training programmes could considerably broaden a director's knowledge and expertise. King IV specifically mentions the value of training for members with limited experience (IoDSA 2016). Unfortunately, not all directors are interested in partaking in such development activities. Some seasoned directors believe they have already spent sufficient time and resources to develop their skills and competencies (Schwizer et al. 2011). They might thus argue that they have been recruited given their existing competencies. As such, they might not value further development opportunities offered by the company. They might even feel insulted if they are expected to participate in continuous development programmes (Coulson-Thomas 2008). A distinction should, however, be made between vocational training on daily activities and training that is industry-specific. Experienced directors ought to realise that they could gain invaluable knowledge on corporate processes and culture by attending information and training sessions (Long 2008).

King IV pertinently states that members of the governing body should continuously develop their competence to lead effectively. The report furthermore indicates that time constraints and potential conflict of interest of different board positions should be 'balanced against the opportunity for professional development' (IoDSA 2016).

According to Coulson-Thomas (2008), the attitudes of the board chair and chief executive officer (CEO) could have a considerable impact on a company's learning culture. Some leaders believe the characteristics and mindset required to be an efficient director cannot be taught, but 'come naturally'.
Consequently, they might not actively encourage fellow directors to participate in continuous learning activities. Training programmes might furthermore be regarded as costly (Schwizer et al. 2011) and time consuming (Long 2008), without clear evidence of the value-adding benefits.

Although there is a considerable body of literature on best practices to improve the skills and knowledge of directors, limited information is available on the actual implementation thereof. Only a few international studies were conducted on board development in the 1990s and mainly centred on the non-profit sector (Holland \& Jackson 1998; Maassen 1999). The Institute of Directors (IoD 1998) in the United Kingdom reported that director development was ineffective during the 1990s. Less than $30 \%$ of their respondents were involved in orientation initiatives and only approximately a fifth were interested in continuous learning. More than 10 years later, studies on director training were still scant (Schwizer et al. 2011). Companies still disclosed limited, generic information on the orientation and development of directors (Roy 2008).

According to Beets and Goodman (2012), too little is known about the effectiveness of executive training in South Africa. Companies should consider evaluating the success of director development initiatives. They could do so by assessing the competencies, skills and knowledge of board members before and after interventions (MacLean 2003; Mallin 2005). Directors could furthermore be requested to provide constructive feedback on development programmes. Further development needs could then be identified based on their responses (Coulson-Thomas 2008; Leblanc 2007; Walker 2009). Such needs should also be considered during succession planning. The timeous development of potential board candidates for their future roles is essential (Conger \& Fulmer 2003). Promising board candidates and inexperienced directors could benefit considerably by working with a coach or mentor, as explained in the following section.

\section{Coaching and mentoring}

Coaching and mentoring are two important development initiatives that are mainly aimed at executives (D'Abate, Eddy \& Tannenbaum 2003). Mentorship of inexperienced individuals was mentioned in King III but no reference was made to coaching in the King III or King IV Reports (IoDSA 2009). King IV pertinently mentions that the governing body's succession plan should include details on the identification, mentorship and development of future candidates. Members with limited governance experience should receive mentoring (IoDSA 2016).

Although there is some overlap between coaching and mentoring development initiatives, there are important differences in terms of their focus, process and goals. Coaching is defined as a professional, collaborative and outcomes-driven learning process that seeks to develop an individual and raise self-awareness so that he or she might achieve specific goals (Coaches and Mentors of South Africa 
2017; Price 2009). According to the British IoD (2018), executive coaching could assist individual directors to address specific professional development issues or to take on a new role.

In contrast, mentoring typically focuses on the long-term career advancement of an individual. D'Abate et al. (2003) distinguished between several forms of mentoring, including formal or structured and informal or unstructured. In most cases, the transfer of knowledge and values from the mentor to the mentee takes place in an informal organisational context (Swap et al. 2001).

De Meuse, Dai and Lee's (2009) meta-analysis shows that most executives who have received coaching demonstrate improved skills and performance. They also found that coachees were more optimistic about the process and outcomes than coaches and companies. Some new board members prefer to be mentored instead of coached, as the former allows them to confidentially discuss concerns and uncertainties (Long 2008).

Groves (2007) reported that mentoring plays a crucial role in both talent development and succession planning. The support of a seasoned mentor could enable a promising candidate to develop the perspectives and vision needed to reach his or her full potential (Clutterbuck \& Megginson 1999). A meta-analysis conducted by Underhill (2006) shows that mentoring generally improves career outcomes. This author reported that informal mentoring produces more significant effects on career outcomes than formal mentoring. As such, the talent pool comprising diverse board candidates could be expanded. Some instances have, however, been noted where female directors purposefully withheld advice from their less experienced counterparts to prevent them from climbing the corporate ladder (Johnson \& Mathur-Helm 2011).

In light of the preceding literature review, the following problem statement and research objectives were formulated.

\section{Problem statement and research objectives}

The authors set out to investigate the board development practices and disclosure of the JSE Top 40 companies over the period 2011 to 2015. The research objectives of this study were twofold. Firstly, to examine the extent of and depth to which the sampled companies reported on their board development initiatives. Secondly, to gain insight into selected board development practices and the reasons for using these mechanisms.

\section{Research design and methodology}

The study commenced in 2011, as it marked the advent of integrated reporting in South Africa for a 5-year period. Given this timeframe, the King III director development guidelines were considered. The JSE Top 40 companies represent more than $80 \%$ of the JSE's total market capitalisation. A possible limitation of the study lies in the fact that these companies are not representative of the entire South African stock market, as it is skewed towards financial and mining companies.

A mixed-methods approach was adopted to give effect to the research objectives. Content analysis was firstly conducted on the annual integrated reports of the considered companies. The following key words were used to conduct word searches in their integrated reports: develop(ment), train(ing), induct(ion), orientate, orientation, professional, program(me), mentor(ing), coach(ing) and brief(ing). The chosen key words were based on the King III director development recommendations and literature applicable to director development.

Disclosures on director development were then coded by employing the dichotomous variables 0 and 1 . A disclosure score of 1 indicated that a company reported on some form of director development during the year under review. A disclosure score of 0 reflected that no information was published or where companies specifically mentioned that they did not engage in director development during the specific year.

Based on details that were disclosed on board development, subjective depth scores of 1, 3 and 5 were allocated. A depth score of 1 indicated that director development was merely mentioned. If some particulars were disclosed, a depth score of 3 was allocated. If an extensive discussion was offered, a depth score of 5 was assigned. In such a case, details were typically divulged on the nature and type of mechanisms employed (formal or informal), the directors involved and the frequency of development interventions. Specific attention was given to whether or not development mechanisms were geared towards new and existing board members.

The coding process resulted in a unique database. To ensure data consistency, one coder meticulously applied the adopted coding system. Given that a degree of subjectivity was involved, a number of cross-checks were conducted. Descriptive and inferential statistics were used to analyse the quantitative data. A mixed-model analysis of variance (ANOVA) test was used to determine the significance of the observed trend in the depth score over the research period. The considered fixed effects factor was 'year' and the random effects factor was 'company'.

In addition to the quantitative analysis, semi-structured personal interviews were conducted with five directors who served on the boards of JSE Top 40 companies. The interviews were employed to gauge the directors' views on particular board development practices. The number of interviews was limited given time constraints. As directors' development needs differ over the duration of their careers, board experience was used as the selection criterion. As such, executive and 
non-executive directors with different levels of experience were selected. The most experienced director had 20 years of experience and the least experienced had only served on a board for 2 years. One interviewee served as a CEO, two as chief financial officers and two as non-executive directors. The interviews were conducted in June and August 2016.

The interview guide, consisting of open-ended questions, was designed to facilitate the semi-structured personal interviews. Biographic information was requested in Section A, followed by questions related to selected director development mechanisms (Section B). Permission was obtained to record and transcribe all of the interviews. All participants provided informed consent. Attention was also given to confidentiality, anonymity and data protection.

As credibility is related to the internal validity of the qualitative research instrument (Shenton 2004), the questions posed were based on King III and other credible academic sources. The research findings were also linked to literature, where applicable. Regarding confirmability, the authors aimed to ensure that the views of the interviewees were correctly reflected. Thematic analysis was conducted to identify common themes.

\section{Ethical considerations}

Ethical clearance was granted by the Humanities research ethics committee at the researchers' university. Reference numbers and status for the quantitative and qualitative data collection are as follows: SU-HSD-002516 (exempt from ethical clearance); SU-HSD-002527 (approved with stipulations).

\section{Results}

In this section, trends in the disclosure and depth scores will be discussed. Reference will also be made to the views of the interviewees on particular director development mechanisms.

\section{Director development disclosure and depth scores}

The disclosure scores that are highlighted in Table 1 reflect the percentage of the JSE Top 40 companies that reported on director development in a specific year.

As reflected in Table 1, the majority of the JSE Top 40 companies reported that they developed their directors in each of the considered years. Some of the largest companies, however, did not report on any board development mechanisms. A slight decrease was observed in the number of companies that mentioned director development in their

\begin{tabular}{lccccc}
\begin{tabular}{l} 
TABLE 1: Director development \\
\hline Disclosure
\end{tabular} & $\mathbf{2 0 1 1}$ & $\mathbf{2 0 1 2}$ & $\mathbf{2 0 1 3}$ & $\mathbf{2 0 1 4}$ & $\mathbf{2 0 1 5}$ \\
score & $\boldsymbol{N ( \% )}$ & $\boldsymbol{N ( \% )}$ & $\boldsymbol{N ( \% )}$ & $\boldsymbol{N ( \% )}$ & $\boldsymbol{N ( \% )}$ \\
\hline Yes (1) & $36(90)$ & $34(85)$ & $36(90)$ & $33(82.5)$ & $32(80)$ \\
No (0) & $4(10)$ & $6(15)$ & $4(10)$ & $7(17.5)$ & $8(20)$ \\
\hline
\end{tabular}

integrated reports in 2015 relative to 2011. It is plausible that some of the companies that received disclosure scores of 0 developed their directors but did not report publicly on such initiatives.

In a 2015 study, the South African Institute of Chartered Accountants (SAICA 2015) stressed the need for more development initiatives to guide 'efficient integrated thinking', and by extension integrated reporting. Director development might, however, be regarded as costly and time consuming, without acknowledging the potential valueadding benefits (Long 2008; Schwizer et al. 2011). As explained earlier, not all leaders support director development initiatives (Coulson-Thomas 2008). As a result, board members might be discouraged from enrolling in such programmes. Details on the director development depth scores are provided in Figure 1.

In 2011, approximately half of the JSE Top 40 companies merely mentioned director development in their integrated reports, as reflected by depth scores of 1 . A gradual increase was observed in the depth of director development information being published over the research period, as illustrated by the increase in the number of 3 and 5 depth scores. Although some particulars were disclosed by 16 companies, only 3 companies offered an extensive discussion on director development in 2015 (depth scores equal to 5).

A mixed-model ANOVA was employed to investigate the significance of differences in the depth scores over the research period. The result was insignificant $(F=0.326$; $p=0.86)$. There is thus still scope for improved reporting on director development for some of South Africa's 40 largest listed companies.

\section{Details on the application of specific director development mechanisms}

As explained in the literature review, companies could employ a range of board development mechanisms. Table 2 reflects the number of companies that annually reported on director development by referring to the identified key words.

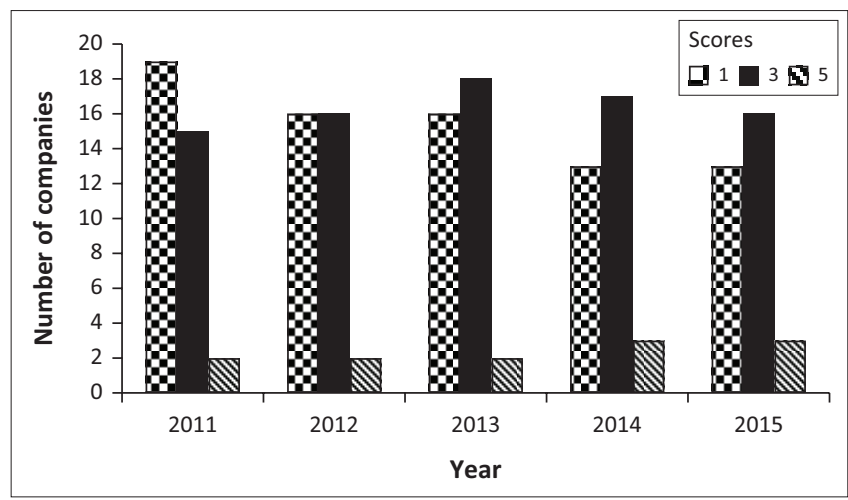

FIGURE 1: Director development depth scores (2011-2015). 
TABLE 2: Reporting on key words.

\begin{tabular}{lccccc}
\hline Key word & $\mathbf{2 0 1 1}$ & $\mathbf{2 0 1 2}$ & $\mathbf{2 0 1 3}$ & $\mathbf{2 0 1 4}$ & $\mathbf{2 0 1 5}$ \\
\hline Induct, induction, orientate or orientation & 30 & 30 & 29 & 32 & 29 \\
Develop or development & 27 & 30 & 31 & 28 & 30 \\
Train or training & 25 & 30 & 32 & 28 & 27 \\
Professional (development program[me]) & 15 & 18 & 17 & 15 & 14 \\
Brief or briefing & 10 & 14 & 14 & 12 & 14 \\
Mentor or mentoring & 4 & 6 & 5 & 4 & 4 \\
Coach or coaching & 1 & 2 & 1 & 1 & 1 \\
\hline
\end{tabular}

As shown in Table 2, most of the companies mentioned that they inducted or orientated newly appointed board members. Although the development of inexperienced directors is a core King III principle (IoDSA 2009), some companies did not refer to developing inexperienced board members. Reference was only made to newly appointed individuals when details on induction or orientations were disclosed.

In the analysis, attention was given to the context within which development took place: whether it was aimed at newly appointed directors, existing board members or the entire directorate. The key words 'train(ing)' and 'develop(ment)' were mainly used in conjunction with a discussion on the director induction programme. Based on the content analysis, it appeared as if training was mainly aimed at new board appointees, instead of the entire directorate. An exception being the companies that obtained depth scores of 5 (refer to Figure 1). These companies paid attention to the induction of new directors and offered details on the specific training initiatives for individual directors, including experienced and newly appointed ones.

Some of the considered companies claimed that it took time and considerable financial resources to successfully implement director development initiatives. Previous scholars such as Long (2008) and Schwizer et al. (2011) had similar observations. The limited reference that was made to continuous development could be partly ascribed to the schedules of directors that do not allow sufficient time for continuous development activities (Mankins \& Steele 2006). This finding might also be ascribed to experienced directors not being interested in such mechanisms, as they feel that they are 'competent enough'.

Less than $50 \%$ of the companies reported that their development programmes were facilitated by professionals. Despite a King III recommendation that directors should be regularly briefed (IoDSA 2009), only approximately a third of the companies offered regular briefings on relevant matters and changes in their operating environment. Briefings could occur during board committee meetings, instead of board meetings. Companies possibly did not report on board committee briefings.

As illustrated in the literature review, mentoring and coaching are informal development mechanisms ( $\mathrm{D}^{\prime}$ Abate et al. 2003; Swap et al. 2001). Based on the content analysis, it seemed as if the majority of the sampled companies did not consider these mechanisms. Some of the companies merely mentioned that mentoring occurred at some stage during a director's corporate progress and that executive coaching occurred without providing details on the process and outcomes thereof. Given the informal nature of mentoring and coaching, this observation is not surprising. The interviewees' responses on four board development themes are explored next.

\section{Induction of new board members}

In line with a King III recommendation (IoDSA 2009), all the interviewees stated that their companies have a director induction or orientation programme. They remarked that these programmes are very beneficial for new and inexperienced directors. One participant indicated that new board members spend time at every department in the company 'to obtain a better understanding of the company's operations'.

Others also mentioned that new executive appointees were rotated throughout their companies. Such opportunities provide them with an 'improved understanding of the business' by learning from peers. MacLean (2003) recommended that teamwork should be encouraged during induction periods. Inexperienced directors could benefit considerably when seasoned directors share knowledge that was accumulated over several years.

Interviewees were furthermore of the opinion that orientation programmes enable incoming directors to adapt more quickly to their new environments. This observation is in line with literature stating that the primary aim of an orientation programme should be to enable newly appointed directors to make meaningful, timeous contributions to their board (Long 2008).

\section{Training and continuous development}

All of the participants have been enrolled in continuous development programmes at some stage during their careers. Their perspectives on the development of executive versus non-executive directors differed considerably. They explained that executives typically proceeded through the corporate ranks over several years. Such individuals are hence familiar with the company's structure and operations when they reach board level. They believed non-executives might derive more value from training on technical issues to gain insight into the wealth creation process. This observation is in line with Walker (2009) who suggested that non-executives could benefit more from training and regular briefings than their executive counterparts, as the former are not involved in the daily operations of the company.

One interviewee explained that because of their Top 40 status, the company can attract top talent. As such, they do not have the same 'exposure to [or need for] grass root development' as their smaller counterparts. In such cases, directors might benefit from participating in 
self-improvement activities if formal development is not offered (Gregory \& Grapsas 2012).

The directors who belonged to a regulatory body (e.g. SAICA) remarked that they are expected to stay up to date on 'profession-related changes'. Previous authors emphasised the value of broadening directors' field-specific knowledge and expertise (Davis \& Callahan 2012; Gregory \& Grapsas 2012). All the interviewees warned against the view that a company is solely responsible for the development of its directors. While a company could provide the resources and development opportunities, individuals should use these opportunities. This finding confirms prior research, suggesting that individuals should take responsibility for their own development (Coleman, Gulati \& Segovia 2012; Fidler 2016).

Although literature indicates that the investment in board development could be optimised if individual development needs are considered and evaluated post-intervention (Leblanc 2007; Mallin 2005; Walker 2009), only one interviewee indicated that his company annually offers such opportunities. None of the directors' companies, however, had formal procedures to measure the effectiveness of director development programmes. Some of the participants remarked that their annual performance evaluations offered some insight into the success of development interventions.

\section{Feedback on regular briefings}

One interviewee remarked that experienced individuals 'do not necessarily require extensive continuous development, but should be regularly informed on changes in the business environment'. All directors agreed that regular briefing on changes in the micro and macro environments is an essential King III recommendation (IoDSA 2009). Three of them emphasised that directors have a personal responsibility to ensure that they are adequately informed of, and respond to, corporate changes.

External entities or experts facilitate regular information sessions on, inter alia, compliance with legislation and the King guidelines. They also receive information on possible cyberattacks, financial aspects and the impact of announcements by rating agencies. One director remarked that information on regulatory developments and challenges in their operating environment is often 'dumped on directors in the form of lengthy reports'. He recommended that companies should rather continuously inform directors by highlighting relevant information.

\section{Feedback on mentoring and coaching}

The non-executive directors who were interviewed valued mentorship more than their executive counterparts. A possible explanation for this observation could be that not all non-executives have corporate backgrounds. Some might be involved in academia or the public sector and could hence benefit considerably from mentoring to understand the corporate context.

Interviewees mentioned that promising senior managers undergo extensive training and shadow executive directors to gain experience. They therefore created the impression that mentoring is typically not employed to develop executive directors after being appointed, but rather during their preceding career path. This finding concurs with prior studies, suggesting that mentoring is a commonly used informal executive development mechanism (D'Abate et al. 2003; Swap et al. 2001).

One interviewee confirmed that if seasoned board members are willing to offer advice and guidance to new appointees, informal learning and mentoring occur. According to this director, structured programmes might, however, be required if the board structure is more 'formal' (and hence less open to informal development).

Other interviewees shared the view that informal mechanisms play a central role in the development of directors. One of the directors remarked that the most valuable development he received during his 20-year tenure was not on technical capabilities but by 'spending time with and listening to experienced directors'. He concluded that if a director can 'get exposure to individuals who take the right risks and are not afraid to step into the unknown, it could be regarded as an invaluable development experience'. Long (2008) likewise emphasised the value of knowledge sharing by seasoned directors.

One of the directors explained that the composition of a board has an impact on its development needs. His company did not offer mentoring at the time when the interview was conducted, as most directors were older than 50 . He was thus of the opinion that there 'will come a time when the company will require new and young board members. Mentorship will then become more important'.

While acknowledging the benefits of mentorship, one interviewee warned against developing directors 'who all think and act in the same way'. Scholars also caution against the so-called group think (Colaco, Myers \& Nitkin 2011). This very experienced director emphasised the importance of having diverse directorates, claiming that individuals who have different views could add value.

Interviewees indicated that mentorship could be an appropriate mechanism to develop previously disadvantaged board candidates. One participant believed that while some companies previously appointed token board members to 'tick the employment equity box, these checklist directors are outdated'. According to Torchia, Calabrò and Huse (2011), a token director is mainly selected to fill a race or gender quota, while giving less attention to his or her possible contribution to the board. This participant added that companies are 
increasingly developing directors to become 'assets and add value to their boards'.

\section{Limitations and suggestions for future research}

A limitation of the study is that all interviewees were white males. The developmental needs and experiences of black and female directors might differ from those of the selected participants. Directors with different levels of experience were chosen to obtain insight into their perspectives on board development initiatives at different companies. In future, interviews could be conducted with newly appointed, diverse board members to determine their opinions on development mechanisms. In addition, interviews could be conducted with mentees before, during and after their participation in a mentorship programme to determine their perspectives on the effectiveness of this development initiative.

As this study was based on the director development practices of the JSE Top 40 companies, the findings are not generalisable to all companies listed on the JSE. The director development disclosure and depth scores were based on the details disclosed in the considered companies' integrated reports. The only exception was if a company made specific reference to an additional source. In future, a similar study could be conducted for a larger sample that includes small, medium and large JSE-listed companies. In addition to integrated reports, disclosures on companies' websites could also be considered.

\section{Conclusions and recommendations}

Literature indicates that director development could contribute to board performance and ultimately corporate performance (Adams \& Ferreira 2009; Brown 2007). In line with the agency theory, shareholders prefer that welldeveloped directors oversee the actions of their corporate agents. Given South Africa's unique development needs, several mechanisms were suggested in the King Reports to develop local directors.

Previous researchers emphasised the importance of directors having the required skills, knowledge and competencies to properly fulfil their roles and responsibilities. The majority of the JSE Top 40 companies developed their directors in line with some of the King III recommendations over the research period. Director development practices were mentioned in 171 of the 200 analysed integrated reports. In 2011, most of the companies that reported on director development only mentioned development mechanisms resulting in depth scores of 1. By 2015, the majority of the companies provided an average discussion concerning their director development practices, as reflected by depth scores of 3 .

Details were mainly disclosed on formal director development mechanisms, including induction and training. Limited information was reported on informal mechanisms, specifically mentoring and coaching. No significant trend in the depth of corporate reporting on director development was noted over the research period.

It was evident from the content analysis that the majority of the companies focused their development efforts on new board appointees. In line with King III, it is recommended that more resources should be allocated to the development of the entire board and not just new and inexperienced directors. Well-developed directors are likely to function more effectively in the constantly changing business environment in comparison to their counterparts who receive limited training. Given the importance of sustainable business practices, it is not surprising that King IV pertinently mentions that ongoing development programmes for boards of retirement funds should include details on responsible investment and environmental, social and corporate governance matters (IoDSA 2016). This recommendation is also apt for directors of listed companies.

Previous authors, notably Coulson-Thomas (2008) and Walker (2009), suggested that directors' training needs should be assessed through regular feedback. Board chairs and CEOs should encourage their directors and, where possible and applicable, provide financial support. The IoDSA and business schools could be consulted in this regard. An internal development division could also contribute considerably to ongoing director development.

Based on the opinions of selected South African board members, it seems as if director development is indeed a valuable mechanism to grow the local talent pool. Promising, diverse candidates should be encouraged to partake in mentoring and coaching initiatives. As King IV emphasises that potential board candidates should be mentored as part of a governing body's succession plan, companies might give more attention to mentoring in future. Inexperienced directors and board candidates should also take personal responsibility to find suitable mentors. Leaders should encourage experienced directors to share their knowledge. A board might otherwise lose extensive know-how when a seasoned director retires.

In line with a warning by the philosopher Heraclitus that 'much learning does not teach understanding' (in Breverton 2009), it was evident that the interviewees regarded director development as an ever-changing process that should be adapted to the needs of a specific company and its board. A balance should be struck between exposing inexperienced directors to seasoned directors' views, while allowing the inexperienced ones the opportunity to share their alternative viewpoints. Ideally, development opportunities should result in an enhanced understanding of the pace and magnitude of change in the corporate environment. A well-developed directorate would be in a better position to fulfil their obligations to shareholders and other key stakeholders than their less developed counterparts. 


\section{Acknowledgements}

The authors extend their gratitude to Professor Martin Kidd for his assistance with the statistical analysis

\section{Competing interests}

The authors declare that they have no financial or personal relationships that may have inappropriately influenced them in writing this article.

\section{Authors' contributions}

N.M-K. conceptualised the article, analysed the data and wrote the first draft of the article. B-M.S. and J.v.S. assisted with the data collection and analyses. S.V. wrote sections of the literature review and ensured compliance with the journal's technical requirements.

\section{References}

Adams, R.B. \& Ferreira, D., 2009, 'Women in the boardroom and their impact on governance and performance', Journal of Financial Economics 94(2), 291-309. https://doi.org/10.1016/j.jfineco.2008.10.007

Beets, K. \& Goodman, S., 2012, 'Evaluating a training programme for executive coaches', SA Journal of Human Resource Management 10(3), 1-10. https://doi. org/10.4102/sajhrm.v10i3.425

Breverton, T., 2009, Immortal words: History's most memorable quotations and the stories behind them, Quercus Publishing, London.

Brown, W.A., 2005, 'Exploring the association between board and organizational performance in non-profit organizations', Non-profit Management and Leadership 15(3), 317-339. https://doi.org/10.1002/nml.71

Brown, W.A., 2007, 'Board development practices and competent board members: Implications for performance', Non-profit Management and Leadership 17(3), 301-317. https://doi.org/10.1002/nml.151

Chen, D., 2008, 'The monitoring and advisory functions of corporate boards: Theory and evidence', Doctoral dissertation, University of Baltimore.

Chinyio, E. \& Olomolaiye, P.O., 2010, Construction stakeholder management, WileyBlackwell, Chichester.

Clutterbuck, D. \& Megginson, D., 1999, Mentoring executives and directors, Routledge, Boston, MA.

Coaches and Mentors of South Africa, 2017, Coaching, viewed 23 July 2017, from https://www.comensa.org.za/Information/Coaching.

Colaco, H.M.J., Myers, P. \& Nitkin, M.R., 2011, 'Pathways to leadership: Board independence, diversity and the emerging pipeline in the United States for women directors', International Journal of Disclosure and Governance 8(2), 122147. https://doi.org/10.1057/jdg.2011.1

Coleman, J., Gulati, D. \& Segovia, W.O., 2012, Passion and purpose: Stories from the best and brightest young leaders, Harvard Business School Publishing, Boston, MA.

Collins, C.J. \& Clark, K.D., 2003, 'Strategic human resource practices, top management team social networks, and firm performance: The role of human resource practices in creating organizational competitive advantage', The Academy of Management Journal 46(6), 740-751. https://doi.org/10.2307/30040665

Conger, J.A. \& Fulmer, R.M., 2003, 'Developing your leadership pipeline', Harvard Business Review 81(12), 76-85.

Coulson-Thomas, C., 2008, 'Developing directors, key questions for the training and development community', Industrial and Commercial Training 40(7), 364-373. https://doi.org/10.1108/00197850810912234

D'Abate, C.P., Eddy, E.R. \& Tannenbaum, S.I., 2003, 'What's in a name? A literaturebased approach to understanding mentoring, coaching, and other constructs that describe developmental interaction', Human Resource Development Review 2(4), 360-384. https://doi.org/10.1177/1534484303255033

Davis, P.J. \& Callahan, W., 2012, 'Professional development for company directors A strategic leadership opportunity for HR? The case of Air Astana', Industria and Commercial Training 44(5), 268-272. https://doi.org/10.1108/00197851 211245013

De Meuse, K.P., Dai, G. \& Lee, R.J., 2009, 'Evaluating the effectiveness of executive coaching: Beyond ROI?', Coaching: An International Journal of Theory, Research and Practice 2(2), 117-134. https://doi.org/10.1080/17521880902882413

Fidler, A., 2016, 'Taking responsibility for your career growth', Executive Secretary Magazine, 25 March, viewed 16 November 2017, from http://executivesecretary. com/taking-personal-responsibility-for-your-career-growth/.
Gregory, H.J. \& Grapsas, R.C., 2012, International comparison of selected corporate governance guidelines and codes of best practice, Weil, Gotshal \& Manges LLP, governance

Groves, K.S., 2007, 'Integrating leadership development and succession planning best practices', Journal of Management Development 26(3), 239-260. https://doi. org/10.1108/02621710710732146

Haskins, M.E. \& Shaffer, G.R., 2009, 'Partnering with your leadership development provider: 12 best practices', Strategic HR Review 8(6), 28-32. https://doi. org/10.1108/14754390910990964

Holland, T.P. \& Jackson, D.K., 1998, 'Strengthening board performance: Findings and lessons from demonstration projects', Non-profit Management and Leadership 9(2), 121-134. https://doi.org/10.1002/nml.9201

Institute of Directors (IoD), 1998, Sign of the times, IoD, London.

Institute of Directors (IoD), 2018, Coaching, viewed 19 February 2018, from https:// www.iod.com/training/bespoke-training/coaching.

Institute of Directors in Southern Africa (IoDSA), 2002, King Report on Corporate Governance for South Africa 2002, IoDSA, Johannesburg.

Institute of Directors in Southern Africa (IODSA), 2009, King Report on Corporate Governance for South Africa 2009, IoDSA, Johannesburg.

Institute of Directors in Southern Africa (IoDSA), 2015, Why competent directors are invaluable, viewed 13 June 2017, from http://www.iodsa.co.za/news/241068/ Why-competent-directors-are-invaluable.htm.

Institute of Directors in Southern Africa (IoDSA), 2016, King IV Report on governance for South Africa 2016, IoDSA, Johannesburg.

International Institute of Directors and Managers, 2017, About us, viewed 13 June 2017, from http://www.iidmglobal.com/about.

Jensen, M.C. \& Meckling, W.H., 1976, 'Theory of the firm: Managerial behavior, agency costs, and ownership structure', Journal of Financial Economics 3(4), 305360. https://doi.org/10.1016/0304-405X(76)90026-X

Johnson, Z. \& Mathur-Helm, B., 2011, 'Experience with queen bees: A South African study exploring the reluctance of women executives to promote other women in the workplace', South African Journal of Business Management 42(4), 47-55.

Leblanc, R.W., 2007, 'Recruitment, training and assessment (and removal) of directors, post SOX', International Journal of Disclosure and Governance 5(1), 8-14. https:// doi.org/10.1057/palgrave.jdg.2050071

Long, T.E., 2008, 'Diving for pearls: The importance of board induction and reinduction', International Journal of Business Governance and Ethics 4(1), 40-50. https://doi.org/10.1504/IJBGE.2008.017890

Maassen, G.F., 1999, An international comparison of corporate governance models, Spencer Stuart, Amsterdam.

MacLean, P.J., 2003, Great boards plain \& simple: A guidebook for non-profit managers $\&$ board members, Silver Creek Press, Edmonton, AB.

Mallin, C., 2005, 'Directors: How training and development can enhance their role', Corporate Governance: An International Review 13(2), 729. https://doi. org/10.1111/j.1467-8683.2005.00465.x

Mankins, M. \& Steele, R., 2006, 'Stop making plans; Start making decisions', Harvard Business Review, January, viewed 15 July 2017, from https://hbr.org/2006/01/ stop-making-plans-start-making-decisions.

Price, J., 2009, 'The coaching/therapy boundary in organizational coaching', Coaching: An International Journal of Theory, Research and Practice 2(2), 135-148. https:// doi.org/10.1080/17521880903085164

Prinsloo, L. \& Shevel, A., 2013, 'Not enough talent for SA's boards', Business Day, 03 March, viewed 02 June 2016, from http://www.bdlive.co.za/business/2013/03/03/ not-enough-talent-for-sa-s-boards.

Republic of South Africa, 2008, Companies Act (No. 71 of 2008), viewed 29 July 2017, from http://www.cipc.co.za/files/2413/9452/7679/CompaniesAct71_2008.pdf.

Roy, M.-J., 2008, 'Building board expertise through key supporting processes', Measuring Business Excellence 12(4), 38-49. https://doi.org/10.1108/136830 40810919953

Schwizer, P., Casiraghi, R. \& Stefanelli, S., 2011, Enhancing board effectiveness: What about induction and training programs for directors?, SSRN, viewed 14 June 2017, from https://papers.ssrn.com/sol3/papers.cfm?abstract_id=1793277.

Shenton, A., 2004, 'Strategies for ensuring trustworthiness in qualitative research projects', Education for Information 22, 63-75. https://doi.org/10.3233/EFI-200422201

South African Institute of Chartered Accountants (SAICA), 2015, Integrated thinking: An exploratory survey, viewed 06 April 2017, from https://www.saica.co.za/ Portals/O/Technical/Sustainability/SAICAIntegratedThinkingLandscape.pdf.

Swap, W., Leonard, D., Shields, M. \& Abrams, L., 2001, 'Using mentoring and storytelling to transfer knowledge in the workplace', Journal of Management Information Systems 18(1), 95-114. https://doi.org/10.1080/07421222.2001.110 45668

Torchia, M., Calabrò, A. \& Huse, M., 2011, 'Women directors on corporate boards: From tokenism to critical mass', Journal of Business Ethics 102(2), 299-317. https://doi.org/10.1007/s10551-011-0815-z

Underhill, C.M., 2006, 'The effectiveness of mentoring programs in corporate settings: A meta-analytical review of the literature', Journal of Vocational Behavior 68(2), 292-307. https://doi.org/10.1016/j.jvb.2005.05.003 
Van Marrewijk, M. \& Werre, M., 2003, 'Multiple levels of corporate sustainability', Journal of Business Ethics 44(2), 4-119.

Viviers, S., Mans-Kemp, N. \& Fawcett, R., 2017, 'Mechanisms to promote board gender diversity in South Africa', Acta Commercii 17(1), 1-10. https://doi. org/10.4102/ac.v17i1.489
Walker, D., 2009, 'A review of corporate governance in UK banks and other financial industry entities: Final recommendations', National Archives, viewed 14 June 2017, from http://webarchive.nationalarchives.gov.uk/+/http:/www.hmtreasury.gov.uk/d/walker_review_261109.pdf.

Wixley, T. \& Everingham, G., 2010, Corporate governance, 3rd edn., Siber Ink, Cape Town. 